\title{
Comparative estimations of betalains and sugars in fruits of five species of Selenicereus (Cactaceae)
}

\section{Comparación del contenido de betalaínas y azúcares en frutos de cinco especies de Selenicereus (Cactaceae)}

\section{Acta Botanica Mexicana}

\author{
Arith F. Pérez-Orozco',20, Victoria Sosal(1)
}

\begin{abstract}
:
Background and Aims: Betalains are water pigments reported for most species in the order Caryophyllales, to which the family Cactaceae belongs, with benefits as antioxidants in nutrition and human health. The objective of this paper is to determine the quantity of the betalains (betaxanthins and betacyanins) and sugars present in five taxa of Selenicereus, from the Hylocereus clade, commonly utilized for their edible fruit, including $S$. ocamponis which is an underutilized species, and scarcely cultivated in Mexico.

Methods: Fruits from wild and cultivated plants were collected in Puebla, Veracruz and Yucatán (Mexico) and Valle del Cauca (Colombia) between April and June 2019, and their betalain and sugar content were estimated from frozen fruit. The method proposed by the Association of Official Analytical Chemists was followed to estimate the sugar content. A spectrophotometric method was utilized for estimation of betalains.

Key results: The highest total betalain content was found in species with fruits of purple pulp and pericarp such as S. ocamponis $(5.30$ and 4.03 $\mathrm{mg} / 100 \mathrm{~g}$ of fresh weight, respectively). Glucose and fructose content was considerable in some samples: $\mathrm{S}$. undatus with 5.99 and $2.87 \mathrm{mg} / 100 \mathrm{~g}$ and $S$. ocamponis with 5.30 and $4.03 \mathrm{mg} / 100 \mathrm{~g}$ respectively.

Conclusions: This study identified large variation in total betalain content in the pericarps of wild and cultivated fruits in S. undatus (2.47-37.11 $\mathrm{mg} / 100 \mathrm{~g}$ of fresh weight), which might be related to their management and selection. Estimated total betalain content of wild plants of this species was higher than in some cultivated plants. These results suggest that wild $S$. undatus plants might represent a good source for breeding programs. The cultivation of species with purple pulp and pericarp should be promoted, so they can be utilized as colorants in food industry.
\end{abstract}

Key words: antioxidant, betacyanin, betaxanthin, fructose, Hylocereus.

\section{Resumen:}

Antecedentes y Objetivos: Las betalaínas son pigmentos solubles en agua reportados para la mayoría de las especies en Caryophyllales, orden al que pertenece la familia Cactaceae. Estos pigmentos poseen beneficios en la nutrición y la salud humana como antioxidantes. El objetivo de este artículo es el de determinar la cantidad de betalaínas (betaxantinas y betacianinas) y azúcares presentes en cinco taxones de Selenicereus, del grupo Hylocereus, los cuales son comúnmente utilizados por sus frutos comestibles, incluyendo $S$. ocamponis, una especie subutilizada y escasamente cultivada en México.

Métodos: Se recolectaron frutos de plantas silvestres y cultivadas en Puebla, Veracruz y Yucatán (México) y el Valle del Cauca en Colombia entre los meses de abril a junio de 2019, y se estimó el contenido de betalaínas y azúcares de sus frutos una vez congelados. Se siguió el método propuesto por la "Association of Official Analytical Chemists" para estimar el contenido de azúcares. Para la determinación de betalaínas se utilizaron métodos espectrofotométricos.

Resultados clave: El mayor contenido de betalaínas se encontró en especies de frutos con pulpa y exocarpio púrpura como S. ocamponis (5.30 y 4.03 $\mathrm{mg} / 100 \mathrm{~g}$ de peso fresco, respectivamente). El contenido de glucosa y fructosa en algunas muestras fue considerable: $S$. undatus con 5.99 y 2.87 $\mathrm{mg} / 100 \mathrm{~g}$ y $\mathrm{S}$. ocamponis con 5.30 y $4.03 \mathrm{mg} / 100 \mathrm{~g}$, respectivamente.

Conclusiones: Este estudio identificó una gran variación en el contenido total de betalaínas en el exocarpio de frutos silvestres y cultivados en $S$. undatus (2.47-37.11 mg/100 g de peso fresco), lo que podría estar relacionado con su manejo y selección. El contenido total estimado de betalaínas de plantas silvestres de esta especie fue más alto que en algunas plantas cultivadas. Estos resultados sugieren que las plantas silvestres de $S$. undatus representan un buen recurso para programas de reproducción. Se debe promover el cultivo de especies con frutos de pulpa y exocarpio de color púrpura para que puedan ser utilizados en la industria alimentaria como colorantes.

Palabras clave: antioxidante, betacianinas, betaxantinas, fructosa, Hylocereus.

${ }^{1}$ Instituto de Ecología, A.C., Biología Evolutiva, Carretera antigua a Coatepec 351, Col. El Haya, 91073 Xalapa, Veracruz, Mexico.

²Author for correspondence: fabiana.perez@inecol.mx
Received: November 3, 2021

Reviewed: December 3, 2021.

Accepted by Marie-Stéphanie Samain: January 13, 2022

Published Online first: January 24, 2022.

Published: Acta Botanica Mexicana 129(2022).

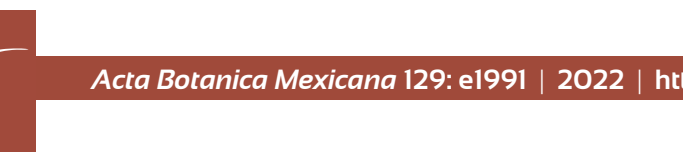

To cite as: Pérez-Orozco, A. F. and V. Sosa. 2022. Comparative estimations of betalains and sugars in fruits of five species of Selenicereus (Cactaceae). Acta Botanica Mexicana 129: e1991. DOI: https://doi. org/10.21829/abm129.2022.1991

e-ISSN: 2448-7589 


\section{Introduction}

Many species of the family Cactaceae bear edible fruits that vary in color from yellow, reddish to purple, resulting from the presence of betalains, and are considered promising new crops suitable for cultivation in semi-arid and arid regions (Stinzing et al., 2003; Mizrahi, 2014). Among them are several hemiepiphytic species in the Hylocereus clade of Selenicereus (A. Berger) Britton \& Rose (Korotkova et al., 2017). They are cultivated around the world and known as dragon fruit, pitahaya or pitaya, although the latter is also used for fruits of Stenocereus (A. Berger) Riccob. in some regions of Mexico (Pimienta-Barrios and Nobel, 1994). Species in this clade are native from Mexico to South America and have been introduced and cultivated, for instance in China, Malaysia, Vietnam and Israel (Vaillant et al., 2005).
Five or six species are the most frequently sold in fruit markets, such as the yellow-fruited Selenicereus megalanthus (K. Schum. ex Vaupel) Moran, native to South America (Fig. 1A, D) (Bauer, 2003; Tel-Zur et al., 2004). It is currently planted in many parts of the Andes in Colombia and Ecuador (Galán Saúco et al., 2014; Buriticá and Cartagena Valenzuela, 2015). Selenicereus undatus (Haworth) D.R. Hunt is the most widely cultivated (Fig. 1C), with its wild distribution ranging from Mexico to Guatemala and the Lesser Antilles, and it has been introduced and is grown in many countries in the Americas and in the rest of the world (Bauer, 2003; Arias and Véliz-Pérez, 2006; Bravo-Hollis and Arias, 2011). This species is characterized by fruits with a whitish pulp and a purplish or dark-pink pericarp (see García de Almeida et al., 2018); a subspecies was described as having a yellow
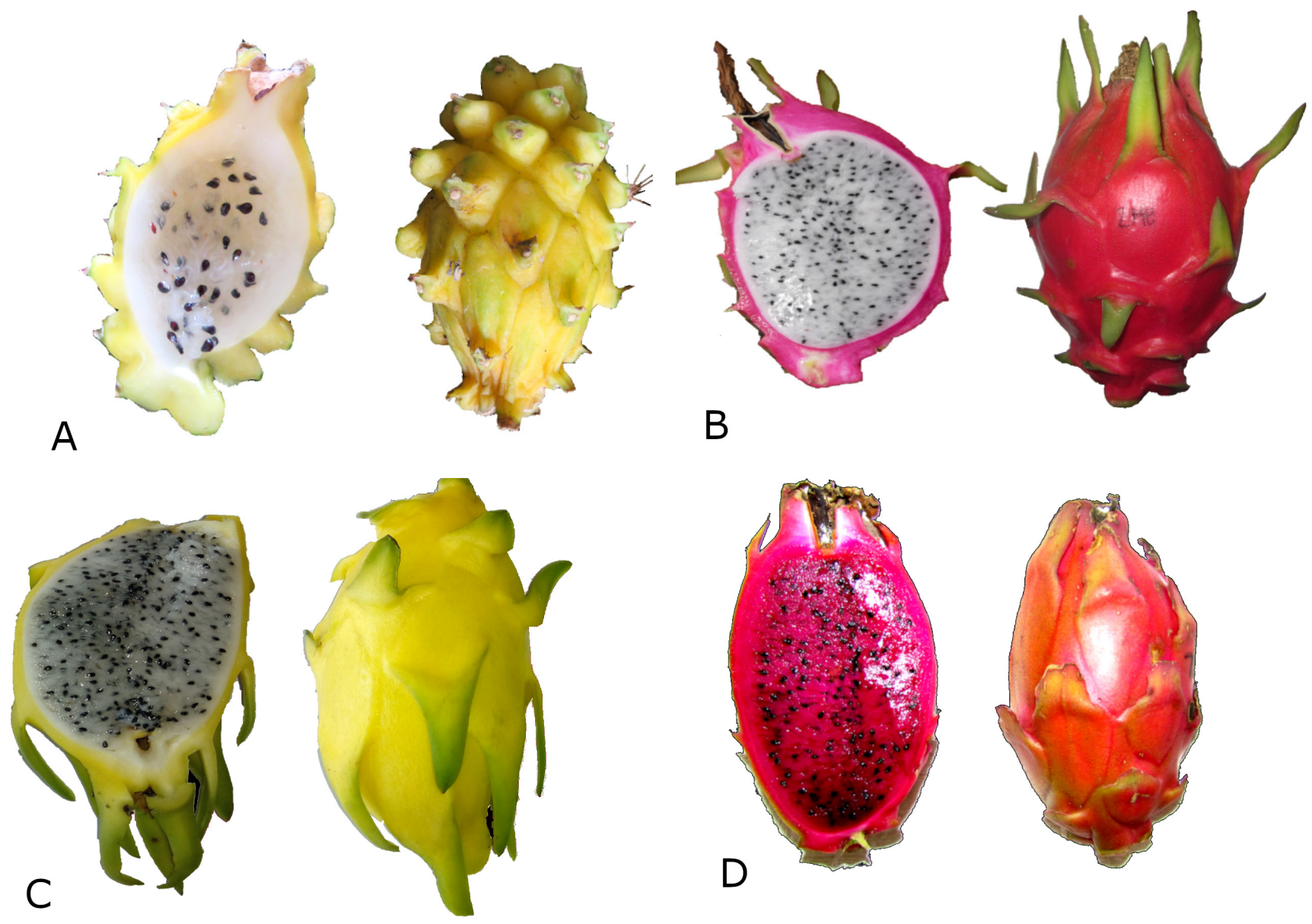

Figure 1: Fruits of pitahayas, longitudinal section showing pulp and seeds left, fruit showing bracts and spines right: A. Selenicereus megalanthus (K. Schum. ex Vaupel) Moran (Valle del Cauca, Colombia); B. Selenicereus ocamponis (Salm-Dyck) D.R. Hunt (Puebla, Mexico); C. Selenicereus undatus (Haw.) D.R. Hunt (Puebla, Mexico); D. Selenicereus undatus subsp. luteocarpus (Cálix de Dios) M.H.J. van der Meer (Quintana Roo). 
pericarp: S. undatus subsp. luteocarpus Cálix de Dios (Cálix De Dios, 2005; Fig. 1B). Selenicereus ocamponis (Salm-Dyck) D.R. Hunt is native to the western Pacific coast in Mexico and Guatemala with purplish pericarp and pulp, and cultivated in home gardens on the Pacific slopes in Mexico (Fig. 1D) (Sosa et al., 2020). Other important cultivated species are S. polyrhizus (F.A.C. Webber) Britton \& Rose and S. costaricensis (F.A.C. Webber) S. Arias \& N. Korotkova, both with red pulp and red to pink pericarp. Their betalain biochemistry and biosynthesis have been widely studied (Qingzhu et al., 2016; Xi et al., 2019). These two latter species have been documented as rich sources of betalains, such as betanidin, betanin, isobetanin, neobetanidin, hylocerein, isohylocerein, phyllocactin, isophyllocactin, betaxanthin and miraxanthin, and variation in pigment concentrations is responsible for the different hues in the pulp and pericarp of their fruits (Wybranec and Mizrahi, 2002; Ibrahim et al., 2018).

Betalains are water soluble pigments containing nitrogen and have been reported for most species in the order Caryophyllales to which Cactaceae belongs (Timoneda et al., 2019). These compounds are present in the leaves, stems, bracts and fruits in the vacuoles of the cells, mainly in epidermal and sub-epidermal tissues (Timoneda et al., 2019). Betalains are utilized as colorants in the food and cosmetic industry; they can substitute chemical dyes with benefits to human health because they have antioxidant properties (Stintzing and Carle, 2004; 2007). Thus, there is considerable interest in documenting the presence of these pigments among plants (Stintzing and Carle, 2004; 2007). Betalains have many applications as colorants in foods, such as desserts, confections, dry mixes, dairy, and meat products (Jayasinghe et al., 2015; Song et al., 2016; Naseer et al., 2019; Rahimi et al., 2019). Among the main advantages to human health is their bioactive potential as antioxidants (Gandía-Herrero et al., 2016; Song et al., 2016; Guerrero-Rubio et al., 2020). Furthermore, estimations of these pigments have been gathered from plants under cultivation, mostly in S. polyrhizus (Wu et al., 2006; De Mello et al., 2014). Nevertheless, evaluation of the additional four species in Selenicereus cultivated for their edible fruits has not yet been carried out and they are considered in this study. These estimations may identify good sources of betalains utilized in the food and cosmetic industry.

The objective of this paper is to determine the quantity of the betalains (betaxanthins and betacyanins) and sugars present in five taxa of Selenicereus from the Hylocereus clade, commonly utilized for their edible fruit, including S. ocamponis, which is an underutilized species. Fruits were collected directly in the field from wild plants, or from plants cultivated in home gardens or growing on small plantations in Mexico and Colombia. Previously obtained results for these species are compared with our results, with the objective of providing data that will encourage the cultivation of these species that offer many benefits to human health.

\section{Material and Methods}

\section{Plant material}

Chemical analyses included Selenicereus species with fruits that have white and pinkish-purple pulp, harvested from April to June, 2019 in several localities in Puebla, Veracruz and Yucatán, in Mexico, as well as in Valle del Cauca, Colombia. Sampling sites were selected to include wild and cultivated plants in home gardens or from plantations. Vouchers and detailed localities are listed in Table 1. The pericarp was separated from the pulp of mature fruits using a steel knife. The fruit was vacuum packed, and subsequently stored at $-40{ }^{\circ} \mathrm{C}$ for further analysis. No attempt was made to eliminate endogenous microorganisms, because fruits were immediately frozen until minutes before extraction, thus potential interference from microorganisms should be very low and equivalent in all samples (Pomeranz and Meolan, 1994).

\section{Sugar determination}

The Association of Official Analytical Chemists methodology was used for sugar content estimation (AOAC, 2012). Sugars were extracted with $80 \%(\mathrm{v} / \mathrm{v})$ ethanol. One g of pulp from each fruit was combined with $30 \mathrm{ml} 80 \%(\mathrm{v} / \mathrm{v})$ ethanol. After stirring for $1 \mathrm{~h}$, a supernatant was obtained by centrifugation (4500 g-force for $30 \mathrm{~min}$ ) (Centrifuge 5804-R, Eppendorf Inc., Enfield, USA). After repeating this procedure, the two supernatants were combined and brought up to a final volume of $100 \mathrm{ml}$ with $80 \%(\mathrm{v} / \mathrm{v})$ ethanol and filtered 
Table 1: Estimated sugar content (g/100 g) for the pulp of the fruits of five taxa of Selenicereus (A. Berger) Britton \& Rose. Values are given in grams per $100 \mathrm{~g}$ of fresh weight in pulp. Georeferences of the vouchers for this study are provided. CUVC=Herbarium Universidad del Valle, Colombia. XAL=Herbarium Instituto de Ecología, A.C. UADY=Herbarium Universidad Autónoma de Yucatán.

\begin{tabular}{|c|c|c|c|c|c|}
\hline Species & $\begin{array}{c}\text { Locality } \\
\text { Georeferences }\end{array}$ & $\begin{array}{c}\text { Voucher } \\
\text { (Herbarium) }\end{array}$ & $\begin{array}{l}\text { Glucose } \\
\text { g/100g }\end{array}$ & $\begin{array}{l}\text { Fructose } \\
\mathrm{g} / 100 \mathrm{~g}\end{array}$ & $\begin{array}{l}\text { Sucrose } \\
\mathrm{g} / 100 \mathrm{~g}\end{array}$ \\
\hline $\begin{array}{l}\text { Selenicereus megalanthus } \\
\text { (K. Schum. ex Vaupel) Moran }\end{array}$ & $\begin{array}{l}\text { Valle del Cauca, Colombia } \\
\left(76^{\circ} 38^{\prime} 24^{\prime \prime} \mathrm{W}, 3^{\circ} 48^{\prime} 36^{\prime \prime} \mathrm{N}\right)\end{array}$ & $\begin{array}{l}\text { C. Ruiz et al. } 556 \\
\text { (CUVC) }\end{array}$ & 0.92 & 2.13 & 0.68 \\
\hline $\begin{array}{l}\text { Selenicereus ocamponis } \\
\text { (Salm-Dyck) D.R. Hunt }\end{array}$ & $\begin{array}{c}\text { Puebla, Mexico } \\
\left(97^{\circ} 24^{\prime} 00^{\prime \prime W}, 18^{\circ} 10^{\prime} 12^{\prime \prime N}\right)\end{array}$ & $\begin{array}{c}\text { C. Ruiz et al. } 672 \\
\text { (XAL) }\end{array}$ & 3.34 & 1.94 & undetected \\
\hline $\begin{array}{l}\text { Selenicereus ocamponis } \\
\text { (Salm-Dyck) D.R. Hunt }\end{array}$ & $\begin{array}{c}\text { Puebla, Mexico } \\
\left(97^{\circ} 21^{\prime} 00^{\prime \prime} \mathrm{W}, 18^{\circ} 18^{\prime} 48^{\prime \prime} \mathrm{N}\right)\end{array}$ & $\begin{array}{c}\text { C. Ruiz et al. s.n. } \\
\text { (XAL) }\end{array}$ & 5.30 & 4.03 & undetected \\
\hline $\begin{array}{l}\text { Selenicereus ocamponis } \\
\text { (Salm-Dyck) D.R. Hunt }\end{array}$ & $\begin{array}{c}\text { Puebla, Mexico } \\
\left(97^{\circ} 15^{\prime} 36^{\prime \prime W}, 18^{\circ} 22^{\prime} 48^{\prime \prime} N\right)\end{array}$ & $\begin{array}{l}\text { C. Ruiz et al. } 676 \\
\text { (XAL) }\end{array}$ & 3.22 & 2.50 & undetected \\
\hline Selenicereus sp. & $\begin{array}{c}\text { Puebla, Mexico } \\
\left(97^{\circ} 21^{\prime} 00^{\prime \prime W}, 18^{\circ} 19^{\prime} 48^{\prime \prime} \mathrm{N}\right)\end{array}$ & $\begin{array}{l}\text { C. Ruiz et al. s.n. } \\
\text { (XAL) }\end{array}$ & 3.51 & 1.89 & undetected \\
\hline Selenicereus sp. & $\begin{array}{c}\text { Puebla, Mexico } \\
\left(96^{\circ} 25^{\prime} 34.8^{\prime \prime} \mathrm{W}, 19^{\circ} 32^{\prime} 24^{\prime \prime} \mathrm{N}\right)\end{array}$ & $\begin{array}{l}\text { C. Ruiz } 694 \\
\text { (XAL) }\end{array}$ & 5.67 & 2.48 & undetected \\
\hline $\begin{array}{l}\text { Selenicereus undatus } \\
\text { (Haw.) D.R. Hunt }\end{array}$ & $\begin{array}{c}\text { Puebla, Mexico } \\
\left(97^{\circ} 22^{\prime} 12^{\prime \prime} \mathrm{W}, 18^{\circ} 10^{\prime} 12^{\prime \prime} \mathrm{N}\right)\end{array}$ & $\begin{array}{l}\text { C. Ruiz et al. } 670 \\
\text { (XAL) }\end{array}$ & 5.99 & 2.87 & undetected \\
\hline $\begin{array}{l}\text { Selenicereus undatus } \\
\text { (Haw.) D.R. Hunt }\end{array}$ & $\begin{array}{c}\text { Veracruz, Mexico } \\
\left(97^{\circ} 10^{\prime} 48^{\prime \prime} \mathrm{W}, 20^{\circ} 22^{\prime} 48^{\prime \prime} \mathrm{N}\right)\end{array}$ & $\begin{array}{c}\text { C. Ruiz et al. s.n. } \\
\text { (XAL) }\end{array}$ & 1.64 & 0.65 & undetected \\
\hline $\begin{array}{l}\text { Selenicereus undatus } \\
\text { (Haw.) D.R. Hunt }\end{array}$ & $\begin{array}{c}\text { Yucatán, Mexico } \\
\text { (89-59'24"W, 2036'00"N) }\end{array}$ & $\begin{array}{c}\text { C. Ruiz \& D. Angulo } 641 \\
\text { (UADY) }\end{array}$ & 2.12 & 0.92 & undetected \\
\hline $\begin{array}{l}\text { Selenicereus undatus subsp. } \\
\text { luteocarpus (Cálix de Dios) M.H.J. } \\
\text { van der Meer }\end{array}$ & $\begin{array}{c}\text { Veracruz, Mexico } \\
\left(98^{\circ} 10^{\prime} 12^{\prime \prime} \mathrm{W}, 20^{\circ} 58^{\prime} 12^{\prime \prime} \mathrm{N}\right)\end{array}$ & $\begin{array}{l}\text { C. Ruiz et al. } 693 \\
\text { (XAL) }\end{array}$ & 4.48 & 2.65 & undetected \\
\hline
\end{tabular}

through a $0.45 \mu \mathrm{m}$ filter. Glucose, fructose and sucrose concentrations were determined by high performance liquid chromatography equipped with an isocratic solvent delivery system, manual injector, refractive index detector, and recording/computing integrator (HPLC System, Shimadzu Co. Ltd., Kyoto, Japan) with a COSMOSIL 5NH2-MS column (Nakarai Tesque Co. Ltd., Kyoto, Japan). Elution was carried out with $80 \%$ acetonitrile at a flow rate of $1 \mathrm{ml} \mathrm{min}^{-1}$. Next, $10 \mu$ of extract was injected directly into the column. The standard was injected in triplicate for the construction of calibration curves. Qualitative analysis of sugar was determined by comparison to the retention time of standards. All determinations were performed in triplicate.

\section{Betalain content}

\section{Extraction and betalain determination}

The method of Wu et al. (2006) was used to obtain a methanolic extract from the fruit. Two grams of pulp and one gram of pericarp were macerated with $20 \mathrm{ml}$ of methanol
$80 \%(\mathrm{v} / \mathrm{v})$. Sonication was applied for 10 min with a Fisher ultrasonic bath (Model FS110, Waltham, USA). Mixtures were then shaken in the dark for $20 \mathrm{~min}$ at room temperature and centrifuged at 2200 g-force in a Hermle centrifuge (Model Z236, Gosheim, Germany). The supernatant was separated, and the residue was subjected to a similar second extraction. The supernatants were pooled, filtered with No. 1 Whatman paper, and concentrated to dryness at $40{ }^{\circ} \mathrm{C}$ in a rotary evaporator (Yamato RE201, Santa Clara, USA). Finally, residues were re-suspended in $10 \mathrm{ml}$ of a solution of methanol $80 \%$ and stored in amber containers at $-20^{\circ} \mathrm{C}$. Betacyanin and betaxanthin concentrations were determined using the spectrophotometric method of Castellanos-Santiago and Yahia (2008) and the calculation: $B=(A \times D F \times W \times V) /(\varepsilon \times P \times L)$, where $B$ is the content of betacyanins or betaxanthins $\left(\mathrm{mg} \mathrm{g}^{-1}\right), A$ is the absorbance (at $538 \mathrm{~nm}$ for betacyanins and $483 \mathrm{~nm}$ for betaxanthins), DF is the dilution factor, $\mathrm{W}$ is the molecular weight (550 $\mathrm{g} \mathrm{mol}^{-1}$ for betanin and $308 \mathrm{~g} \mathrm{~mol}^{-1}$ for indicaxanthin), $\varepsilon$ is the molar extinction coefficient $\left(60,000 \mathrm{~L} \mathrm{~mol}^{-1} \mathrm{~cm}^{-1}\right.$ for 
betanin and 48,000 $\mathrm{L} \mathrm{mol}^{-1} \mathrm{~cm}^{-1}$ for indicaxanthin), $\mathrm{P}$ is the mass of the sample $(\mathrm{g})$, and $L$ is the length $(1 \mathrm{~cm})$ of the cuvette used during the determination. Results were expressed as total content of betalains per $100 \mathrm{~g}$ of fresh weight, through the sum of the contents of betacyanins and betaxanthins. All determinations were performed in triplicate and summarized by their mean value and standard deviation.

\section{Data analysis}

For total betalains, betaxathines and betacyanins contents, we used the t-test to compare among pairs of species when appropriate (Zar, 2010). The analyses were performed in $R$ (R Core Team, 2021).

\section{Results}

Regarding sugar content, Table 1 presents the estimates for glucose, fructose and sucrose. Glucose and fructose content in some samples was considerable. Selenicereus undatus with 5.99 and $2.87 \mathrm{mg} / 100 \mathrm{~g}$ and $\mathrm{S}$. ocamponis with 5.30 and $4.03 \mathrm{mg} / 100 \mathrm{~g}$ respectively. Table 2 presents the results of the estimated betacyanins, betaxanthins and the total betalain content for the five Selenicereus species we collected in the wild, in home gardens and small plantations. Total betalain (Table 2) content was highest ( $32.46 \mathrm{~g} / 100 \mathrm{~g}$ fresh tissue) in the pericarp of the unidentified purplish red Selenicereus ( $t=5.7$, d.f. $=3, P=0.01$ ), while S. ocamponis (16.6 g/100 g fresh tissue) and S. undatus (17.57 g/100 g fresh tissue) did not differ significantly $(t=0.3$, d.f. $=4, P=0.72)$. A similar pattern of differences was observed in betacyanins in the pericarp. The unidentified Selenicereus (23.76 g/100 g fresh tissue) had the highest content ( $t=9.2$, d.f. $=3, P=0.002)$, but $S$. undatus (11.57 $\mathrm{g} / 100 \mathrm{~g}$ fresh tissue) had on average $18 \%$ more betacyanins than S. ocamponi ( $13.73 \mathrm{~g} / 1000 \mathrm{~g}$ fresh tissue) and differed significantly ( $t=2.8$, d.f. $=4, P=0.47$ ). Moreover, the unidentified species ( $8.7 \mathrm{~g} / 100 \mathrm{~g}$ fresh tissue) had the highest content of betaxanthins in the pericarp ( $t=6.1, d . f .=3, P=0.008$ ), while there were no significant differences ( $t=1.9$, d.f. $=4$, $\mathrm{P}=0.13$ ) between $\mathrm{S}$. ocamponis $(5.03 \mathrm{~g} / 100 \mathrm{~g}$ fresh weight) and S. undatus ( $3.84 \mathrm{~g} / 100 \mathrm{~g}$ of fresh tissue). In contrast, in the pulp of fruits there were no significant differences in

Table 2: Betacyanins, betaxanthins and total betalain content estimated for five studied taxa of Selenicereus (A. Berger) Britton \& Rose from different localities. Values are given in milligrams per $100 \mathrm{~g}$ of fresh weight. Vouchers and herbaria codes are the same as in Table 1. Values are means \pm standard deviations of triplicate analysis $(n=3)$.

\begin{tabular}{|c|c|c|c|c|c|c|c|c|}
\hline \multirow{2}{*}{ Species } & \multirow{2}{*}{ Habitat } & \multirow{2}{*}{ Country } & \multicolumn{2}{|c|}{ Betacyanins } & \multicolumn{2}{|c|}{ Betaxanthins } & \multicolumn{2}{|c|}{ Total betalains } \\
\hline & & & Pulp & Pericarp & Pulp & Pericarp & Pulp & Pericarp \\
\hline $\begin{array}{l}\text { Selenicereus megalanthus } \\
\text { (K. Schum. ex Vaupel) Moran }\end{array}$ & Plantation & Colombia & undetected & $0.67 \pm 0.07$ & undetected & $2.31 \pm 0.32$ & undetected & $2.98 \pm 0.38$ \\
\hline $\begin{array}{l}\text { Selenicereus ocamponis } \\
\text { (Salm-Dyck) D.R. Hunt }\end{array}$ & $\begin{array}{l}\text { Home } \\
\text { garden }\end{array}$ & Mexico & $3.73 \pm 0.09$ & $7.87 \pm 0.43$ & $1.87 \pm 0.16$ & $3.51 \pm 0.19$ & $5.60 \pm 0.25$ & $11.38 \pm 0.23$ \\
\hline $\begin{array}{l}\text { Selenicereus ocamponis } \\
\text { (Salm-Dyck) D.R. Hunt }\end{array}$ & $\begin{array}{l}\text { Home } \\
\text { garden }\end{array}$ & Mexico & $4.29 \pm 0.04$ & $8.83 \pm 0.41$ & $1.86 \pm 0.04$ & $4.23 \pm 0.53$ & $6.18 \pm 0.04$ & $13.06 \pm 0.81$ \\
\hline $\begin{array}{l}\text { Selenicereus ocamponis } \\
\text { (Salm-Dyck) D.R. Hunt }\end{array}$ & $\begin{array}{l}\text { Home } \\
\text { garden }\end{array}$ & Mexico & $3.33 \pm 0.04$ & $18.01 \pm 0.43$ & $1.42 \pm 0.04$ & $7.35 \pm 0.60$ & $4.73 \pm 0.08$ & $25.36 \pm 0.88$ \\
\hline $\begin{array}{l}\text { Selenicereus undatus } \\
\text { (Haw.) D.R. Hunt }\end{array}$ & $\begin{array}{l}\text { Home } \\
\text { garden }\end{array}$ & Mexico & undetected & $29.85 \pm 1.04$ & undetected & $7.27 \pm 0.56$ & undetected & $37.11 \pm 4.0$ \\
\hline $\begin{array}{l}\text { Selenicereus undatus } \\
\text { (Haw.) D.R. Hunt }\end{array}$ & $\begin{array}{l}\text { Home } \\
\text { garden }\end{array}$ & Mexico & undetected & $1.75 \pm 0.08$ & undetected & $0.71 \pm 0.12$ & undetected & $2.47 \pm 0.19$ \\
\hline $\begin{array}{l}\text { Selenicereus undatus } \\
\text { (Haw.) D.R. Hunt }\end{array}$ & Wild & Mexico & undetected & $9.59 \pm 0.32$ & undetected & $3.54 \pm 0.39$ & undetected & $13.13 \pm 0.71$ \\
\hline $\begin{array}{l}\text { Selenicereus undatus subsp. } \\
\text { luteocarpus Calix de Dios }\end{array}$ & $\begin{array}{l}\text { Home } \\
\text { garden }\end{array}$ & Mexico & undetected & $0.27 \pm 0.02$ & undetected & $0.65 \pm 0.12$ & undetected & $0.92 \pm 0.14$ \\
\hline Selenicereus sp. (purplish-red) & Cultivated & Mexico & $4.23 \pm 0.36$ & $16.23 \pm 0.44$ & $2.06 \pm 0.15$ & $6.53 \pm 0.40$ & $6.39 \pm 0.30$ & $22.76 \pm 0.70$ \\
\hline Selenicereus sp. (purplish-red) & Cultivated & Mexico & $5.39 \pm 0.18$ & $31.29 \pm 1.18$ & $1.49 \pm 0.06$ & $10.86 \pm 0.32$ & $6.86 \pm 0.14$ & $42.16 \pm 1.50$ \\
\hline
\end{tabular}


betalains, betacyanins and betaxanthins among the species $(t<0.77$, d.f. $=4, P>0.49$ ).

\section{Discussion}

Our estimations are the first for Selenicereus megalanthus in which low total betalain content was determined in the pericarps of its fruits (Table 2). Fruits of this species are yellowish and although they did not contain elevated betaxanthins, the combination of betalains and betaxanthines resulted in a pale-yellow color of the studied fruits. Remarkably, elevated variation in betacyanins and betaxanthins in S. undatus was identified. This might be related to the management and selection that plants have been subjected to in the communities where they are cultivated, both in home gardens and on plantations. Furthermore, the hue in pericarps of fruits in Cactaceae depends on the combination of betaxanthins and betacyanins (Gandía-Herrero et al., 2016).

Previously, betalains were reported for Selenicereus polyrhizus cultivated in Malaysia (Gengatharan et al., 2015), Taiwan (Wu et al., 2006) and Indonesia (Priatni and Pradita, 2015) (Table 3). This species has a purplish pulp and pericarp. Higher quantities of betalains were recorded in $S$. polyrhizus compared with our estimates for S. ocamponis, with the same pericarp and pulp colors (Table 3). However, the methods were different from those used in our study (Stinzing et al., 2003; Stinzing and Carle, 2007; Naderi et al., 2012). Furthermore, in S. polyrhizus only betacyanins have been detected, as betaxanthins are absent, giving the pulp of its fruits a glowing red-purple color (Stinzing et al., 2002). In addition to previous records, the dry fruits of two undetermined Selenicereus sp. from Nicaragua (Montoya-Arro- yo et al., 2014) and Costa Rica (Esquivel et al., 2007) were analyzed following different protocols but revealed a similar sugar content to that which we report for S. ocamponis.

Earlier estimates of betalains of the pericarps of Selenicereus undatus fruits from Brazil utilizing a different method detected an elevated content (101 g/100 g) (Table 3) (De Mello et al., 2014). Plants were collected in a plantation from Embrapa Cerrado in Brazil, which possibly included plants selected for having intensely colored pericarps to be utilized in the food industry (De Mello et al., 2014).

We included two different species that we could not assign to the known species of Selenicereus, with deep purplish pericarps and pulp and with a high total betalain, betacyanins and betaxanthins content. Estimates of betalain content from S. ocamponis and the two undetermined Selenicereus were elevated, indicating that they are promising crops as a source of these compounds, which as mentioned above, have many applications in the food industry. Furthermore, in the estimates obtained in this study, wild S. undatus plants with purplish fruit had a higher betalain content than some of the cultivated plants. Even though the whitish pulp of $S$. undatus does not contain betalains, it is worth cultivating this pitahaya for its nutritional potential. This pitahaya is also remarkable because it has very large fruits, with purplish pericarps that provide visual quality with extraordinary sensory characteristics, which adds value to these fruits on the international fruit market (Mercado-Silva, 2018).

The results of this study corroborate that pitahayas or dragon fruits are nutritious crops. Selenicereus undatus -the most cultivated species - displayed variation in sugar content. For fruits from certain plants collected in

Table 3: Previous estimations of betanins (or betacyanins) obtained by solvent extraction and quantification by spectrophotometry. References utilized the name Hylocereus (A. Berger) Britton \& Rose, the genus that was transferred to Selenicereus (Korotkova et al., 2017). Hylocereus polyrhizus (F.A.C. Weber) Britton \& Rose, is considered a synonym of S. monacanthus (Lem.) D.R. Hunt (Korotkova et al., 2017).

\begin{tabular}{lcccc}
\hline Species & Country & Tissue & $\begin{array}{c}\text { Betanin } \\
\text { (mg/100 g fresh weight) }\end{array}$ & Source \\
\hline Hylocereus polyrhizus (F.A.C. Weber) Britton y Rose & Indonesia & Pericarp & 73.2 & Faridah et al., 2015 \\
Hylocereus polyrhizus (F.A.C. Weber) Britton y Rose & Indonesia & Pericarp & $515.2^{*}$ & Priatni and Pradita, 2015 \\
Hylocereus polyrhizus (F.A.C. Weber) Britton y Rose & Taiwan & Pericarp & 13.0 & Wu et al., 2006 \\
Hylocereus polyrhizus (F.A.C. Weber) Britton y Rose & Taiwan & Pulp & 10.3 & Wu et al., 2006 \\
Selenicereus undatus (Haw.) D.R. Hunt & Brazil & Pericarp & 101.0 & De Mello et al., 2014 \\
\hline
\end{tabular}


the wild or cultivated ones, as well as fruits of the subsp. luteocarpus, estimates of glucose and fructose were high. Moreover, the estimates of elevated sugars in wild plants of $S$. undatus suggest that it could be used as a resource for pitahaya breeding. Interestingly, estimates for sugars in S. ocamponis were elevated. This pitahaya is cultivated on small plantations and in home gardens on the Pacific slopes of Mexico and has a purple pericarp and pulp. Thus, the potential of this species is enormous for use in the food industry as colorant.

\section{Conclusions}

Estimates of sugars and betalains in wild and cultivated Selenicereus undatus and $S$. ocamponis plants corroborated the importance of pitahayas as healthy fruits that can provide natural colorants for the food and cosmetic industry. Wild plants of these species represent good sources for breeding programs. Selenicereus sp. and S. ocamponis are underutilized species with fruits that have an elevated content of betalains and that should be promoted for cultivation.

\section{Author contributions}

VS conceived the project, planned, and conducted fieldwork. AFP processed the samples, extracted and quantified betalains, and did the statistical analyses. The text was prepared by both authors.

\section{Funding}

This research was supported by the "Consejo Nacional de Ciencia y Tecnología" (CONACYT), Mexico, to Victoria Sosa (PNDP2015/1023).

\section{Acknowledgements}

We thank Sonia Galicia and Ninfa Portilla for their help in the lab. We also thank Bianca Delfosse for her editorial work on our English.

\section{Literature cited}

AOAC. 2012. Official Methods of Analysis. Association of Official Analytical Chemists (AOAC), 19th ed. Washington, DC, USA.

Arias, S. and M. E. Véliz-Pérez. 2006. Diversidad y distribución de las Cactaceae en Guatemala. In: Cano, E. B. (ed.).
Biodiversidad de Guatemala. Universidad de Guatemala. Guatemala, Guatemala. Pp. 229-238.

Bauer, R. 2003. A synopsis of the tribe Hylocereeae F. Bux. Cactaceae. Bulletin of the International Cactaceae Systematics Group 17: 1-61.

Bravo-Hollis, H. and S. Arias. 2011. Cactaceae. Flora Mesoamericana 2(1): 1-78.

Buriticá, P. and J. R. Cartagena Valenzuela. 2015. Neotropical and introduced fruits with special tastes and consistencies that are consumed in Colombia. Revista Facultad Nacional de Agronomía-Medellín 68(2): 7589-7618.

Cálix de Dios, H. 2005. A new subspecies of Hylocereus undatus (Cactaceae) from southeastern Mexico. Haseltonia 11: 11-17. DOI: https://doi.org/10.2985/10700048(2005)11[11:ANSOHU]2.0.CO;2

Castellanos-Santiago, E. and E. M. Yahia. 2008. Identification and quantification of betalains from the fruits of 10 Mexican prickly pear cultivars by high-performance liquid chromatography and electrospray ionization mass spectrometry. Journal of Agricultural and Food Chemistry 56(14): 5758-5764. DOI: https://doi.org/10.1021/jf800362t

De Mello, F. R., C. Bernardo, C. Odebrecht-Dias, L. Gonzaga, E. R. Amante, R. Fett and L. M. Bileski Candido. 2014. Antioxidant properties, quantification and stability of betalains from pitaya (Hylocereus undatus) peel. Ciência Rural, Santa Maria 45(2): 323-328. DOI: https://doi.org/10.1590/01038478 cr20140548

Esquivel, P., F. C. Stintzing and R. Carle. 2007. Comparison of morphological and chemical fruit traits from different pitaya genotypes (Hylocereus sp.) grown in Costa Rica. Journal of Applied Botany and Food Quality 81(1): 7-14.

Faridah, D., D. Syukri and R. Holinesti. 2015. Simple characterization of betalain compound from red pitaya (Hylocereus polyrhizus) peel solution. International Journal of Advanced Science, Engineering and Information Technology 5: 56-60.

Galán Saúco, V., M. Herrero and J. I. Hormaza. 2014. Tropical and subtropical fruits. In: Dixon, G. and D. Aldous (eds.). Horticulture: plants for people and places, Vol. 1. Springer. Dordrecht, Netherlands. Pp. 123-157. DOI: https://doi. org/10.1007/978-94-017-8578-5_5

Gandía-Herrero, F., J. Escribano and F. García-Carmona. 2016. Biological activities of plant pigments betalains. Critical 
Review in Food Science and Nutrition 56(6): 937-945. DOI: https://doi.org/10.1080/10408398.2012.740103

García de Almeida, O. J., L. A. de Souza, A. A. Sartori-Paoli, A. R. Davis y J. H. Cota-Sánchez. 2018. Pericarp development in fruit of epiphytic cacti: implications for fruit classification and macro-morphology in the Cactaceae. Botany 96(9): 621-635. DOI: https://doi.org/10.1139/cjb-2018-0074

Gengatharan, A., G. A. Dykes and W. S. Choo. 2015. Stability of betacyanin from red pitahaya (Hylocereus polyrhizus) and its potential application as a natural colourant. Food Science and Technology 51: 427-434.

Guerrero-Rubio, M. A., J. Escribano, F. García-Carmona and F. Gandía-Herrero. 2020. Light emission in betalains: from fluorescent flowers to biotechnological applications. Trends in Plant Science 25(2): 159-175. DOI: https://doi. org/10.1016/j.tplants.2019.11.001

Ibrahim, S. R. M., G. A. Mohamed, A. Khedr, M. F. Zayed and A. A. S. El-Kholy. 2018. Genus Hylocereus: beneficial phytochemicals, nutritional importance, and biological relevance - a review. Journal of Food Biochemistry 42(2): e12491. DOI: https://doi.org/10.1111/jfbc.12491

Jayasinghe, O., S. Fernando, V. Jayamanne and D. Hettiarachchi. 2015. Production of a novel fruit-yogurt using dragon fruit (Hylocereus undatus L.). European Scientific Journal 11(3): 208-215.

Korotkova, N., T. Borsch and S. Arias. 2017. A phylogenetic framework for the Hylocereeae (Cactaceae) and implications for the circumscription of the genera. Phytotaxa 327(1): 1-46. DOI: https://doi.org/10.11646/phytotaxa.327.1.1

Mercado-Silva, E. M. 2018. Pitaya: Hylocereus undatus (Haw.). In: Rodrigues, S., S. Ebenezer and E. de Brito (eds.). Exotic Fruits Reference Guide, Academic Press-Elsevier. London, UK. Pp. 339-348.

Mizrahi, Y. 2014. Vine-cacti pitayas: the new crops of the world. Revista Brasileira de Fruticultura 36(1): 124-138. DOI: https://doi.org/10.1590/0100-2945-452/13

Montoya-Arroyo, A., R. M. Schweiggert, M. L. Pineda-Castro, M. Sramek, R. Kohlus, R. Carle and P. Esquivel. 2014. Characterization of cell wall polysaccharides of purple pitaya (Hylocereus sp.) pericarp. Food Hydrocolloids 35: 557-564. DOI: https://doi.org/10.1016/j.foodhyd.2013.07.010

Naderi, N., H. M. Ghazali, A. S. M. Hussin, M. Amid and M. Y. A. Manap. 2012. Characterization and quantification of dragon fruit (Hylocereus polyrhizus) betacyanin pigments extracted by two procedures. Pertanika Journal of Tropical Agricultural Science 35(1): 33-40.

Naseer, S., S. Hussain and A. Abid. 2019. Betalain as a food colorant: its sources, chemistry and health benefits. Proceedings of the Pakistan Academy of Sciences 56(2): 3137.

Pimienta-Barrios, E. and P. Nobel. 1994. Pitaya (Stenocereus spp., Cactaceae): an ancient and modern fruit crop of Mexico. Economic Botany 48: 76-83.

Pomeranz, Y. and C. Meolan. 1994. Food analysis: theory and practice. Chapman \& Hall. New York, USA. Pp. 32-34.

Priatni, S. and A. Pradita. 2015. Stability study of betacyanin extract from red dragon fruit (Hylocereus polyrhizus) pericarps. Procedia Chemistry 16: 438-444. DOI: https:// doi.org/10.1016/j.proche.2015.12.076

Qingzhu, H., C. Chengjie, C. Zhe, C. Pengkun, M. Yuewen, W. Jingyu, Z. Jian, H. Guibing, Z. Jietang and Q. Yonghua. 2016. Transcriptomic analysis reveals key genes related to betalain biosynthesis in pulp coloration of Hylocereus polyrhizus. Frontiers in Plant Science 6: 1179. DOI: https:// doi.org/10.3389/fpls.2015.01179

Rahimi, P., S. Abedimanesh, S. A. Mesbah-Namin and A. Ostradahimi. 2019. Betalains, the nature-inspired pigments, in health and diseases. Critical Reviews in Food Science and Nutrition 59(18): 2949-2978. DOI: https://doi.org/10.1080/ 10408398.2018.1479830

R Core Team. 2021. R: A language and environment for statistical computing. R Foundation for Statistical Computing. Vienna, Austria.

Song, H., Z. Zheng, J. Wu, J. Lai, Q. Chu and X. Zheng. 2016. White pitaya (Hylocereus undatus) juice attenuates insulin resistance and hepatic steatosis in diet-induced obese mice. PlosOne 11(2): e0149670. DOI: https://doi.org/10.1371/ journal.pone.0149670

Sosa, V., C. Ruiz-Domínguez and B. E. Gutiérrez-Rodríguez. 2020. Hylocereus ocamponis, una especie de pitaya mexicana poco conocida: un recurso promisorio. Cactáceas y Suculentas Mexicanas 65(1): 4-13.

Stintzing, F. C. and R. Carle. 2004. Functional properties of anthocyanins and betalains in plants, food and human nutrition. Trends in Food Science and Nutrition 15(1): 1938. DOI: https://doi.org/10.1016/j.tifs.2003.07.004 
Stintzing, F. C. and R. Carle. 2007. Betalains -emerging prospects for food scientists. Trends in Food Science and Technology 18(10): 514-525. DOI: https://doi.org/10.1016/j. tifs.2007.04.012

Stintzing, F. C., A. Schieber and R. Carle. 2002. Betacyanins in fruits from red-purple pitaya, Hylocereus polyrhizus (Weber) Britton \& Rose. Food Chemistry 77(1): 101-106. DOI: https://doi.org/10.1016/S0308-8146(01)00374-0

Stintzing, F. C., A. Schieber and R. Carle. 2003. Evaluation of colour properties and chemical quality parameters of cactus juices. European Food Research Technology 216: 303-311. DOI: https://doi.org/10.1007/s00217-002-0657-0

Tel-Zur, N., S. Abbo, D. Bar-Zvi and Y. Mizrahi. 2004. Genetic relationships among Hylocereus and Selenicereus vine cacti (Cactaceae): Evidence from hybridization and cytological studies. Annals of Botany 94(4): 527-534. DOI: https://doi. org/10.1093/aob/mch183

Timoneda, A., T. Feng, H. Sheehan, N. Walker-Hale, B. Pucker, S. Lopez-Nieves, R. Guo and S. Brockington. 2019. The evolution of betalain biosynthesis in Caryophyllales. New Phytologist 224(1): 71-85. DOI: https://doi.org/10.1111/ nph.15980
Vaillant, F., A. Perez, I. Davila, M. Dornier and M. Reynes. 2005. Colorant and antioxidant properties of red-purple pitahaya (Hylocereus sp.). Fruits 60(1): 3-12. DOI: http://dx.doi. org/10.1051/fruits:2005007

Wu, L.-C., H.-W. Hsu, Y.-C. Chen, C.-C. Chiu, Y-I. Lin and J.-A. Ho. 2006. Antioxidant and antiproliferative activities of red pitaya. Food Chemistry 95(2): 319-327. DOI: https://doi. org/10.1016/j.foodchem.2005.01.002

Wybranec, S. and Y. Mizrahi. 2002. Fruit flesh betacyanin pigments in Hylocereus cacti. Journal of Agriculture and Food Chemistry 50(21): 6086-6089. DOI: https://doi. org/10.1021/jf020145k

Xi, X., Y. Zong, S. Li, D. Cao, X. Sun and B. Liu. 2019. Transcriptome analysis clarified genes involved in betalain biosynthesis in the fruit of red pitayas (Hylocereus costaricensis). Molecules 24(3): 445. DOI: https://doi.org/10.3390/ molecules 24030445

Zar, J. H. 2010. Biostatistical Analysis. $5^{\text {th }}$ Ed. Pearson. Upper Saddle River, USA. 960 pp. 